Discussion Paper No. 06-068

\title{
The Impact of Thin-Capitalization Rules on Multinationals' Financing and Investment Decisions
}

Thiess Buettner, Michael Overesch, Ulrich Schreiber and Georg Wamser

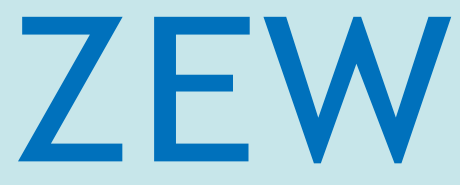

Zentrum für Europäische Wirtschaftsforschung $\mathrm{GmbH}$

Centre for European

Economic Research 
Discussion Paper No. 06-068

\title{
The Impact of Thin-Capitalization Rules on Multinationals' Financing and Investment Decisions
}

\author{
Thiess Buettner, Michael Overesch, \\ Ulrich Schreiber and Georg Wamser
}

Download this ZEW Discussion Paper from our ftp server:

ftp://ftp.zew.de/pub/zew-docs/dp/dp06068.pdf

Die Discussion Papers dienen einer möglichst schnellen Verbreitung von neueren Forschungsarbeiten des ZEW. Die Beiträge liegen in alleiniger Verantwortung der Autoren und stellen nicht notwendigerweise die Meinung des ZEW dar.

Discussion Papers are intended to make results of ZEW research promptly available to other economists in order to encourage discussion and suggestions for revisions. The authors are solely responsible for the contents which do not necessarily represent the opinion of the ZEW. 


\section{Non-Technical Summary}

Tax planning of multinational corporations receives a lot of attention by tax administration and policy-makers. Well-known strategies of tax deferral, transfer pricing, or the use of intercompany loans in order to finance investment and many more, often rather complex, strategies are often feared to erode the corporation tax base. The adverse revenue consequences are a temptation for tax policy to change details in the tax law or its administration and sometimes restrict the use of certain types of tax-planning. However, it is not obvious that an attempt to restrict tax-planning is very effective. Moreover, if it is effective, it is not clear that the corporations' response to a restriction is generally beneficial for the imposing country. Since, as has been discussed in the theoretical literature, restricting certain opportunities for tax-planning might result in adverse consequences for the level of investment undertaken by multinationals in high-tax countries which may also reinforce tax-competition.

One particularly important element in multinational corporations' tax-planning is their ability to structure the finances in terms of debt and equity not only for the corporation as a whole but also internally. Apart from the direct revenue losses, enhanced opportunities for saving taxes may give the multinational an advantage against companies operating only at a national level. For those reasons, governments often impose restrictions on the capital structure choice. In fact, the imposition of so called Thin-Capitalization rules, which deny interest deductions on intercompany debt if the debt-equity ratio or interest 
expenses exceed certain thresholds, is widespread. However, evidence on the effects of restrictions on corporate financing and investment decisions is generally lacking.

This paper investigates the effects of Thin-Capitalization rules on multinationals' financing and investment decisions. A theoretical model considers the financing and investment decisions of a multinational corporation and shows the basic consequences of imposing Thin-Capitalization rules for the debt-asset ratio as well as for the level of investment. The theoretical model indicates that the positive effect of local taxes on leverage is reduced if a Thin-Capitalization rule is imposed. Moreover, it is shown that a Thin-Capitalization rule leads to a higher tax sensitivity of investment decisions.

The empirical analysis employs a comprehensive micro-level panel database of virtually all German multinationals made available for research by the German Bundesbank. The results show a significant positive impact of local taxes on the financial structure but also an adverse impact of Thin-Capitalization rules indicating that these rules are effective to some extent. Moreover, investment is found to be more sensitive to taxes if debt finance is restricted supporting the theoretical concerns about reinforced tax competition. 


\title{
The Impact of Thin-Capitalization Rules on Multinationals' Financing and Investment Decisions
}

\author{
Thiess Buettner
}

(Ifo Institute and Munich University (LMU)) $)^{\dagger}$

\section{Michael Overesch}

(ZEW)

\section{Ulrich Schreiber}

(Mannheim University and ZEW)

\section{Georg Wamser}

(Ifo Institute)

August 2006

\begin{abstract}
This paper analyzes the role of Thin-Capitalization rules for capital structure choice and investment decisions of multinationals. A theoretical analysis shows that the imposition of such rules tends to affect not only the leverage and the level of investment but also their tax-sensitivity. An empirical investigation of leverage and investment reported for affiliates of German multinationals in 24 countries in the period between 1996 and 2004 offers some support for the theoretical predictions. While Thin-Capitalization rules are found to be effective in restricting debt finance, investment is found to be more sensitive to taxes if debt finance is restricted.
\end{abstract}

Keywords: Corporate Income Tax, Multinationals, Leverage, Thin-Capitalization Rules, Firm-Level Data

JEL Classification: H25, H26, G32

\begin{tabular}{|c|c|c|c|}
\hline \multirow[t]{4}{*}{${ }^{\dagger}$ Address: } & Ifo Institute for Economic Research & Phone: & +498992241319 \\
\hline & Poschingerstr. 5 & Fax: & +498992242319 \\
\hline & D-81679 Munich & & \\
\hline & Germany & E-mail: & buettner@ifo.de \\
\hline
\end{tabular}




\section{Introduction}

While all companies can be expected to respond to taxation and capital market conditions with their financing and investment decisions, transnational or, in general, multinational corporations seem to have enhanced opportunities to do so. This includes well-known strategies of tax deferral, transfer pricing, or the use of intercompany loans in order to finance investment but extends to many more, often rather complex, strategies. While it is difficult to assess to which extent the transnational corporations' efforts in tax-planning activities contribute to the low turnout of corporate tax revenue in countries like the US or Germany, at least for the case of the US, tax-planning by multinationals seems to be an important factor (Gravelle, 2004, Desai, 2005). The adverse revenue consequences are a temptation for tax policy to change details in the tax law or its administration and sometimes restrict the use of certain types of tax-planning. However, the many dimensions along which the multinational corporation can structure its activities have already let to rather complex national tax policies with regard to transnational activities (Gresik, 2001). In this situation, it is not obvious that an attempt to restrict tax-planning is very effective. Moreover, if it is effective, it is not clear that the corporations' response to a restriction is generally beneficial for the imposing country. Since, as has been discussed in the theoretical literature, restricting certain opportunities for tax-planning might result in adverse consequences for the level of investment undertaken by multinationals in high-tax countries which may also reinforce tax-competition (e.g., Keen, 2001, and Peralta, Wauthy, and van Yperserle, 2006, see also Janeba and Smart, 2003, and Panteghini, 2006). 
One particularly important element in multinational corporations' tax-planning is their ability to structure the finances in terms of debt and equity not only for the corporation as a whole but also internally (Desai, Foley, and Hines, 2004). Apart from the direct revenue losses, enhanced opportunities for saving taxes may give the multinational an advantage against companies operating only at a national level. For those reasons, governments often impose restrictions on the capital structure choice. In fact, the imposition of so called ThinCapitalization rules, which deny interest deductions on intercompany debt if the debt-equity ratio or interest expenses exceed certain thresholds, is widespread. In 1996 half of the 24 OECD countries considered in the empirical analysis below have imposed those rules. Until 2004 the share has increased to almost 75\%. Despite its widespread use, however, evidence on the effects of restrictions on corporate financing and investment decisions is generally lacking.

In this paper we investigate the effects of Thin-Capitalization rules on multinationals' financing and investment decisions. A theoretical model shows the basic consequences of imposing Thin-Capitalization rules on the subsidiary of a foreign corporation for the debt-asset ratio as well as for the level of investment. The empirical analysis employs a comprehensive microlevel panel database of virtually all German multinationals made available for research by the German Bundesbank. As in the analysis of Desai, Foley, and Hines (2004) the panel data structure and the possibility to identify all foreign affiliates belonging to the same multinational allow us to control for the heterogeneity across companies. A further advantage of the data is that under German tax law repatriated foreign profits are almost completely exempt 
from corporation taxes such that taxation at the location of the affiliate is decisive for the financing and investment decisions of affiliates. The results show a significant positive impact of local taxes on the financial structure but also an adverse impact of Thin-Capitalization rules indicating that these rules are effective to some extent. Moreover, investment is found to be more sensitive to taxes if debt finance is restricted supporting the theoretical concerns about reinforced tax competition.

The paper is structured as follows. The next section provides a theoretical background considering the financing and investment decisions of a multinational corporation and derives empirical implications. More specifically, we model a company, active in two countries, which uses equity and debt subject to the presence of Thin-Capitalization rules. Section 3 discusses the empirical implications for leverage and investment and discusses the investigation approach. The subsequent sections provide an empirical analysis using panel-data for the German multinationals in the period from 1996 until 2004. Section 4 gives a short description of the dataset, before Section 5 presents the results. Section 6 contains the conclusions.

\section{Theoretical Background}

Standard theories of the capital structure (e.g., Myers, 2001, Auerbach, 2002) emphasize that in making their capital structure choice corporations trade off the gains from an increase in 
the leverage, obtained through a larger interest deduction from taxable profits, against the increase in the agency cost of debt, reflecting the inability to solve potential conflict between equity and debt claimants by means of contracts. Assuming that a corporation has more than one location, this approach could be extended also to a transnational or multinational company. However, in this case affiliates have improved access to credit as the company might use intercompany loans rather than only external credit in order to increase the leverage of affiliates in high-tax countries. The financing decision of the multinational corporation, thus, may be particularly sensitive to local tax rates with adverse consequences for the local tax revenue.

Facing the increased ability of multinational corporations to make use of the tax shield by debt in high-tax countries, governments are tempted to restrict the use of debt by means of Thin-Capitalization or Earning-Stripping rules. Those rules typically limit interest deduction up to a fixed relation between equity and debt, usually qualified as the debt which is financed by a shareholder, or deny the deduction of interest expenses above certain thresholds. Then, the interest paid for an excess leverage cannot be deducted from the tax base. In practice, Thin-Capitalization rules are often not limited to debt directly financed by shareholders. Tax administration or legislation will usually also prohibit what is known as back-to-back constructions, where the affiliate issues external debt, which is, however, guaranteed or secured by a deposit from the parent-company. ${ }^{1}$ To keep the following discussion simple, we will treat the Thin-Capitalization rule mostly as a restriction on debt finance without

\footnotetext{
${ }^{1}$ An example is constituted by the US Earnings Stripping rules (Sec. 163 (j) IRC).
} 
always distinguishing between internal and external debt. Nevertheless, for the empirical analysis we should keep in mind that Thin-Capitalization rules does not restrict the interest deduction of all kinds of debt.

To derive the impact of Thin-Capitalization restrictions on corporate decisions we model the decisions of a multinational company with two locations 1 and 2 which is assumed to maximize the following profit function

$$
\begin{aligned}
\pi & =\left(1-\tau_{1}\right) f\left(k_{1}\right)+\left(1-\tau_{2}\right) f\left(k_{2}\right) \\
& -\left[\left(1-\tau_{1}\right) i_{1} \lambda_{1} k_{1}+\left(1-\tau_{2}\right) i_{2} \lambda_{2} k_{2}\right] \\
& -\left[\left(1-\lambda_{1}\right) k_{1}+\left(1-\lambda_{2}\right) k_{2}\right] r \\
& -\left[c_{1}\left(\lambda_{1}\right) k_{1}+c_{2}\left(\lambda_{2}\right) k_{2}\right] \\
& -\left[\left(\lambda_{1}-\bar{\lambda}_{1}\right) \varphi_{1} i_{1} k_{1} \tau_{1}+\left(\lambda_{2}-\bar{\lambda}_{2}\right) \varphi_{2} i_{2} k_{2} \tau_{2}\right] .
\end{aligned}
$$

where $f\left(k_{j}\right)$ denotes the output at location $j$ where $k_{j}$ units of capital are employed. $\tau_{j}$ is the local tax rate on capital income. The second and third lines capture the interest and opportunity cost of capital, where $\lambda_{j}$ denotes the share of capital financed with debt, $i_{j}$ is the rate of interest for debt issued in country $j$, and $r$ indicates the opportunity cost of equity capital. Before considering the profit function further, let us briefly discuss the tax incentive for using a higher leverage. Suppose that $i_{2}$ is not different from $r$. Then a shift towards debt finance at location 2 (higher $\lambda_{2}$ ) will tend to raise profits as a larger part of the earnings of capital is tax deductible. Even in this situation the corporation will not 
finance all capital with debt due to the agency cost of debt. This is captured by the fourth line, which introduces the agency cost determined by a function of each subsidiary's debtequity ratio $c_{j}\left(\lambda_{j}\right){ }^{2}$ In order to facilitate the analysis, the agency cost function is assumed to be convex. ${ }^{3}$ The agency cost function is indexed with the host country to reflect the potential role of this country's credit-market regulations and conditions for the underlying conflict between debtors and creditors. Note that the importance of this conflict might very well also vary between firms. But, since we are concerned with a single firm, this is not captured in the specification of the profit function. The imposition of a Thin-Capitalization rule is reflected by the fifth line, where the profit function is extended to take account of the additional tax payments arising from an excess leverage above the limit $\bar{\lambda}_{j}$. In order to consider cases with and without restrictions on the tax deduction of interest, we will set $\varphi_{j}=1$ if a Thin-Capitalization rule exists in country $j$ and $\varphi_{j}=0$, otherwise. If $\varphi_{j}=1$, the restriction imposed is binding when $\lambda_{j}>\bar{\lambda}_{j}$.

For the optimum share of debt used by an affiliate, say firm 2, we obtain the first-order

\footnotetext{
${ }^{2}$ Note that the agency cost function is kept rather simple. A more general specification would allow for cross-subsidiary effects of the leverage on the agency cost $c_{i}\left(\lambda_{j}, \lambda_{i}\right)$. However, if the own effect dominates the empirical predictions would not change.

${ }^{3}$ More specifically,

$$
c_{j, \lambda} \equiv \frac{\partial c_{j}}{\partial \lambda_{j}}>0
$$
}

and

$$
c_{j, \lambda \lambda} \equiv \frac{\partial^{2} c_{j}}{\partial \lambda_{j}^{2}}>0 .
$$


condition

$$
r-\left(1-\tau_{2}\right) i_{2}-\varphi_{2} i_{2} \tau_{2}-c_{2, \lambda}\left(\lambda_{2}\right) \stackrel{!}{=} 0
$$

Accordingly, the leverage is determined by the cost of equity relative to debt. If $\varphi_{2}=0$ and $r>\left(1-\tau_{2}\right) i_{2}$, the convexity of $c_{2}$ implies that $\lambda_{2}$ is positive. In other words, if the after-tax rate of interest is below the required return on equity, there will be some borrowing. If $\varphi_{2}$ equals 1 , the marginal cost of borrowing jumps up to $i_{2}$ as the tax deduction is no longer granted. As a consequence, the leverage $\lambda_{2}$ is reduced. If $r>i_{2}$ a leverage will still be chosen above $\bar{\lambda}_{2}$, but if $i_{2}>r>i_{2}\left(1-\tau_{2}\right)$ we have a corner solution such that the leverage is chosen to be just equal to the threshold level $\bar{\lambda}_{2}$.

The first-order condition for the capital stock at location 2 is

$$
\left(1-\tau_{2}\right) f^{\prime}\left(k_{2}\right)-\left(1-\tau_{2}\right) \lambda_{2} i_{2}-\left(\lambda_{2}-\overline{\lambda_{2}}\right) \varphi_{2} i_{2} \tau_{2}-\left(1-\lambda_{2}\right) r-c_{2}\left(\lambda_{2}\right) \stackrel{!}{=} 0 .
$$

Accordingly, the stock of capital is chosen such that the after-tax marginal product equals the marginal cost of the investment consisting of the interest cost (second and third term), of the opportunity rate of return (fourth term), and of the agency cost of debt (last term). Without restrictions on debt finance $\left(\varphi_{2}=0\right)$, the borrowing costs are reduced due to the tax deduction. If a Thin-Capitalization rule is imposed and binding $\left(\varphi_{2}=1\right)$, the tax deduction is limited, borrowing is more costly, and the costs of the investment are increased. The consequence will be a lower level of investment. 
With regard to empirical implications it is important to note that the imposition of restrictions on debt finance will not only affect the capital structure and the level of investment of capital; it will also affect the sensitivity of investment and leverage to the tax rate. The tax sensitivity of investment is of particular interest, as it would usually be an important determinant of a country's tax policy. To study the impact on the tax sensitivity, let us derive the comparative static effects of an increase in the tax rate by differentiating the two first-order conditions while taking $\varphi_{j}$ as parametric

$$
\begin{gathered}
{\left[\begin{array}{cc}
-c_{2, \lambda \lambda} & 0 \\
r-\left(1-\tau_{2}\right) i_{2}-\varphi_{2} i_{2} \tau_{2}-c_{2, \lambda} & f^{\prime \prime}\left(k_{2}\right)\left(1-\tau_{2}\right)
\end{array}\right]\left[\begin{array}{l}
d \lambda_{2} \\
d k_{2}
\end{array}\right]} \\
=\left[\begin{array}{c}
-\left(1-\varphi_{2}\right) i_{2} \\
f^{\prime}\left(k_{2}\right)-i_{2} \lambda_{2}+\left(\lambda_{2}-\overline{\lambda_{2}}\right) \varphi_{2} i_{2}
\end{array}\right] d \tau_{2} .
\end{gathered}
$$

With regard to the tax effect on the leverage we can derive

$$
\frac{d \lambda_{2}}{d \tau_{2}}=\frac{\left(1-\varphi_{2}\right) i_{2}}{c_{2, \lambda \lambda}}
$$

First, consider the case without a Thin-Capitalization rule $\left(\varphi_{2}=0\right)$. Given the above assumptions, the term is positive and the strength of the response depends on the interest rate and on the agency cost function. But, if there is a Thin-Capitalization rule in place and is binding $\left(\varphi_{2}=1\right)$, the tax rate effect disappears. 
With regard to the effect on the level of investment at location 2 we obtain

$$
\frac{d k_{2}}{d \tau_{2}}=\frac{f^{\prime}\left(k_{2}\right)-i_{2} \lambda_{2}+\varphi_{2} i_{2}\left(\lambda_{2}-\bar{\lambda}_{2}\right)}{f^{\prime \prime}\left(k_{2}\right)\left(1-\tau_{2}\right)}
$$

To simplify matters let us consider the impact relative to the stock of capital

$$
\frac{d \log k_{2}}{d \tau_{2}}=-\frac{1}{\left(1-\tau_{2}\right) \eta_{2}}\left[1-\frac{i_{2} \lambda_{2}-\varphi_{2} i_{2}\left(\lambda_{2}-\bar{\lambda}_{2}\right)}{f^{\prime}\left(k_{2}\right)}\right],
$$

where $\eta_{2}=-\frac{f^{\prime \prime}\left(k_{2}\right) k_{2}}{f^{\prime}\left(k_{2}\right)}$ is the absolute value of the elasticity of the marginal product. If this elasticity is non-decreasing in the level of capital $k_{2},{ }^{4}$ we can state that the lower level of investment $k_{2}$ and the lower deduction of interest cost under conditions of a Thin-Capitalization rule $\left(\varphi_{2}=1\right)$ will lead to a higher tax sensitivity of the capital stock. ${ }^{5}$ The intuition for this result is that with lower tax deductions a larger part of the earnings is affected by the corporation tax. The corporation tax exerts, therefore, stronger effects on investment.

The profit function utilized to derive these comparative static effects embodies the implicit

\footnotetext{
${ }^{4}$ This assumption is not particularly restrictive. With production function of Cobb-Douglas type, for instance, the elasticity of the marginal product would be constant.

${ }^{5}$ To see this, note that the squared brackets on the right-hand side simplify to

$$
\left[1-\frac{i_{2} \lambda_{2}}{f^{\prime}\left(k_{2}\right)}\right], \quad \text { if } \varphi=0
$$

compared with

$$
\left[1-\frac{i_{2} \bar{\lambda}_{2}}{f^{\prime}\left(\bar{k}_{2}\right)}\right], \quad \text { if } \varphi=1
$$

where $\bar{k}_{2}$ is the amount of capital invested under financial constraints, which, as we know from the first-order condition, cannot exceed $k_{2}$. Thus, we know that $\frac{i_{2} \bar{\lambda}_{2}}{f^{\prime}\left(\bar{k}_{2}\right)}$ is smaller than $\frac{i_{2} \lambda_{2}}{f^{\prime}\left(k_{2}\right)}$, which proves our statement.
} 
assumption that the interest rate for the subsidiary located in, say, country 2 is the local rate of interest $i_{2}$. In case of an intercompany loan this seems questionable as the lending part of the multinational could charge a different interest rate. In fact, if the firm could freely determine financial transfers between its subsidiaries it could completely shift profits out of the high-tax location (Mintz and Smart, 2005). Yet, under the arm's length principle the corporation would have to charge an interest rate not much different from the market rate. Thus, if we assume that all debt at location 2 is internal, the profit function would differ only in using the same interest rate at the lending and the borrowing part of the company, $i_{1}$ in our example. As long as the after-tax rate of interest is below the required return on equity

$$
r>\left(1-\tau_{2}\right) i_{1}
$$

the comparative static effects are not changed, qualitatively. However, the empirical analysis below is not focused on the impact of the interest rate and also does not distinguish between internal and external debt. But, we should keep in mind that depending on the importance of intercompany loans not only the local interest rate in the host country of the affiliate matters but also that in other locations such as the parent's country. 


\section{Empirical Implications}

The first-order conditions and the corresponding comparative static effects suggest that the leverage of the affiliate in country $j$ is a declining function of the after-tax rate of interest, if no Thin-Capitalization rule is imposed. Then, a lower interest rate and a higher tax rate would lead to an increase in the leverage. But, if a Thin-Capitalization rule is imposed in the host country and is binding, the leverage will be reduced and will show less tax sensitivity.

In order to empirically test these predictions we first specify an estimation equation for the leverage of an investment in country $j$ held by company $k$ in period $t$

$$
L E V_{j, k, t}=a_{0}+a_{1} x_{j, k, t}+a_{2} \tau_{j, t}+a_{3} \log i_{j, t}+a_{4} T H C_{j, t}+a_{5} \tau_{j, t} T H C_{j, t}+a_{k}+a_{t}+\epsilon_{j, k, t}^{L E V} .
$$

where $a_{t}$ is a time-specific and $a_{k}$ is a company-specific effect. Note that the former also captures the interest rate at the parent location if we consider a set of companies which share the same parent location. The company-specific effect encompasses the companyspecific opportunity cost of capital which might include elements of personal taxation at the level of the shareholder. It will also control for company-specific determinants of the agency cost of debt. $x_{j, k, t}$ captures further characteristics of the subsidiary which affect the use of debt or the access to credit. As the interest rate $i_{j, t}$ is more difficult to measure, instead of using the after-tax rate of interest $\left(1-\tau_{j, t}\right) i_{j, t}$, the above specification separates out interest and tax rates and makes use of the fact, that the tax rate can be regarded as 
an approximation to the log of unity minus tax rate. In order to allow for the case where a Thin-Capitalization rule is imposed we introduce a dummy $T H C_{j, t}$ indicating whether such a rule is imposed or not, where we expect $a_{4}$ to show a negative sign. To test for the reduced tax sensitivity we include a further interaction term with the tax rate where $a_{5}$ should show the opposite sign than $a_{2}$. Note that the estimation simply introduces information about the existence of a Thin-Capitalization rule but no further information about how likely it may be that the constraints will restrict the capital structure choice of the individual corporation. This reflects first-of all the difficulty to assess in greater detail the specific rules in each country. Moreover, we should note that whether or not a rule is binding is co-determined by the government and the individual company. Therefore, the use of information about how likely the rule is binding raises problems of identification.

With regard to the stock of capital invested by the affiliate an empirical analysis is much more involved as the production function as well as the market conditions for the final product will be different for each firm and investment - even if we have neglected those differences in the theoretical analysis. Hence, it might be useful to include further controls which capture differences in the cost of production, as, for instance, labor cost or distance as an indicator of transport cost, or which capture product-market conditions as the market size, proxied, for instance, by the level of GDP. Of course, some of the details of the tax system need also to be taken into account. In fact, whereas the theoretical analysis above was essentially concerned with the statutory tax rate, in case of investment the depreciation allowances should be taken into account as well. The tax savings from depreciation are introduced by 
means of an interaction term of the present value of depreciation allowances $\left(d_{j, t}\right)$ with the statutory tax rate, formally denoted by $d_{j, t} \tau_{i, t}$.

Following the above theoretical discussion a reasonable specification for the amount of capital invested is

$$
\begin{aligned}
\log C A P_{j, k, t}= & b_{0}+b_{1} z_{j, k, t}+b_{2} \tau_{j, t}+b_{3} i_{j, t} \\
& +b_{4} T H C_{j, t}+b_{5} T H C_{j, t} \tau_{j, t}+b_{6} d_{j, t} \tau_{j, t}+b_{k}+b_{t}+\epsilon_{j, k, t}^{C A P} .
\end{aligned}
$$

where $b_{t}$ is a time-specific and $b_{k}$ is a company-specific effect. $z_{j, k, t}$ contains several controls, which may or may not be company specific. These will reflect differences in the market size, in the local production cost, or in variables which affect the capital structure choice as captured above by $x_{j, k, t}$.

As above, we might want to test the implications of Thin-Capitalization rules. To test for an impact on the level of investment we introduce a dummy for the imposition of such rules in the host country. A different tax sensitivity of the capital stock is tested for by an interaction term between the Thin-Capitalization dummy and the statutory tax rate, where $b_{5}$ should be negative if the tax sensitivity is increased. 


\section{Data and Descriptive Statistics}

The empirical analysis employs micro-level data for multinationals provided by the German Bundesbank. This includes a comprehensive annual database of direct investment stocks of German enterprises held abroad. More precisely, the data provides information about each foreign subsidiary's balance sheet and some further information about the ownership and about the German investor. In its current version, firm-level panel data for foreign subsidiaries are available for the period 1996 to 2004. Data collection is enforced by German law, which determines reporting mandates for international transactions. ${ }^{6}$

Since our model is concerned with a multinational corporation which jointly determines the capital structure at both affiliates we focus on majority owned subsidiaries. As the model assumes a two-tier company structure, also indirectly held investment is excluded. Furthermore, as the underlying model deals with a case where production takes place at each location, holdings and financial service providers as well as observations with non-positive capital and turnover are excluded.

In order to capture the tax incentive on the capital structure, the analysis employs the statutory tax rate on corporate income modified by applicable restrictions on interest deductions,

\footnotetext{
${ }^{6}$ Sec. 26 Aussenwirtschaftsgesetz (Law on Foreign Trade and Payments) in connection with Aussenwirtschaftsverordnung (Foreign Trade and Payment Regulations). Each German multinational has to report its foreign assets including both direct FDI and indirect FDI conditional on some lower threshold level for mandatory reporting. Since 2002, FDI has to be reported, if the participation is $10 \%$ or more and the balance sheet total of the foreign object is above 3 Million Euro. For details see Lipponer (2006). Though previous years showed lower threshold levels, we apply this threshold level uniformly for all years in the panel.
} 
Table 1: Descriptive Statistics

\begin{tabular}{|c|c|c|c|c|}
\hline$\overline{\text { Variable }}$ & 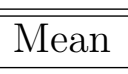 & Std.Dev. & Min. & Max. \\
\hline \multicolumn{5}{|c|}{ Firm level variables } \\
\hline Property, Plant, and Equipment (PPE) (€ 1 Mill.) & 10.3 & 101 & .0001 & 14,400 \\
\hline Turnover $(€ 1$ Mill.) & 50.7 & 344 & 1 & 51,900 \\
\hline Leverage & .609 & .249 & .0002 & 1 \\
\hline Loss carry-forward & .293 & .455 & 0 & 1 \\
\hline \multicolumn{5}{|l|}{ Tax variables } \\
\hline Statutory tax rate & .344 & .071 & .1 & .532 \\
\hline PVD (d) & .795 & .054 & .664 & .914 \\
\hline Thin-Capitalization dummy & .772 & .420 & 0 & 1 \\
\hline \multicolumn{5}{|c|}{ Further characteristics } \\
\hline Lending rate & 7.17 & 3.99 & 1.77 & 27.31 \\
\hline Hourly labor cost (US $\$$ ) & 16.56 & .644 & 2.73 & 34.64 \\
\hline GDP (Bill. US \$) & 1,685 & 2,866 & 17.5 & 11,734 \\
\hline Distance (in km) & 1,963 & 3,126 & 190 & 16,431 \\
\hline Corruption perception & 6.92 & 1.73 & 3.42 & 10.0 \\
\hline
\end{tabular}

43,626 observations representing 24 countries observed over the period 1996 to 2004. 
such as in the case of the Italian local business tax (IRAP). Thus, the statutory tax rate represents the tax savings from deducting one unit of interest.

Since the effective tax reduction from using debt might be zero if a subsidiary carries forward any losses for tax purposes (MacKie-Mason, 1990), we also use a dummy variable indicating whether some loss carry-forward is reported. Of course, the existence of some losses in the previous periods may capture other characteristics of the current decision problem of the company, such as the expected performance of an affiliate. Thus, the overall effect on leverage might well be ambiguous.

As the firm-level data does not provide any information about firm-specific interest expenses, we employ the lending rates for the private sector taken from the IMF International Financial Yearbook augmented, where possible, with data from the European Central Bank. Furthermore, in order to control for company-specific variation in the borrowing conditions we employ the turnover, as an indicator of the size and the cash-flow of the affiliate both of which will generally be positively associated with the borrowing conditions faced by the affiliate. As agency cost may also vary across industries, we control for further heterogeneity by including dummies for 71 industries at the level of the affiliate.

With regard to the analysis of the level of capital we employ some additional controls. This includes hourly labor cost in manufacturing as available from the Bureau of Economic Analysis. We also employ a distance variable which has proved important in previous analysis of FDI. This variable will capture the distance of the foreign affiliate to its German parent. 
Table 2: German Outbound FDI 1996 - 2004

\begin{tabular}{|c|c|c|c|c|c|}
\hline \multirow[t]{2}{*}{ Host Country } & \multicolumn{2}{|c|}{ Observations } & \multirow{2}{*}{$\begin{array}{c}\text { Capital } \\
(€ 1,000) \\
\text { Mean }\end{array}$} & \multirow{2}{*}{$\begin{array}{c}\text { Share of } \\
\text { Debt } \\
\text { Mean }\end{array}$} & \multirow[t]{2}{*}{ TCR } \\
\hline & Number & Percent & & & \\
\hline Australia & 958 & 2.20 & 17,757 & .620 & 1 \\
\hline Austria & 2,590 & 5.94 & 25,429 & .606 & 0 \\
\hline Belgium & 1,868 & 4.28 & 38,768 & .631 & 1 \\
\hline Canada & 782 & 1.79 & 30,501 & .534 & 1 \\
\hline Czech Republic & 2,534 & 5.81 & 25,781 & .614 & 1 \\
\hline Denmark & 757 & 1.74 & 19,145 & .654 & $1 b)$ \\
\hline Finland & 355 & 0.81 & 24,937 & .556 & 0 \\
\hline France & 5,456 & 12.51 & 26,439 & .643 & 1 \\
\hline Great Britain & 3,710 & 8.50 & 29,535 & .590 & 1 \\
\hline Greece & 404 & 0.93 & 22,246 & .651 & 0 \\
\hline Hungary & 1,591 & 3.65 & 36,795 & .561 & $1^{a)}$ \\
\hline Ireland & 363 & 0.83 & 20,856 & .506 & 0 \\
\hline Italy & 3,289 & 7.54 & 29,036 & .720 & $0^{d}$ \\
\hline Japan & 1,096 & 2.51 & 55,661 & .670 & 1 \\
\hline Luxembourg & 41 & 0.09 & 17,188 & .702 & $1^{c)}$ \\
\hline Netherlands & 2,354 & 5.40 & 28,554 & .576 & 1 \\
\hline Norway & 370 & 0.85 & 22,843 & .603 & 0 \\
\hline Poland & 2,949 & 6.76 & 19,905 & .602 & $1 b)$ \\
\hline Portugal & 573 & 1.31 & 26,079 & .561 & 0 \\
\hline Slovakia & 466 & 1.07 & 31,423 & .569 & $1 e)$ \\
\hline Spain & 2,729 & 6.26 & 33,348 & .607 & 1 \\
\hline Sweden & 1,041 & 2.39 & 20,701 & .616 & 0 \\
\hline Switzerland & 2,931 & 6.72 & 19,025 & .547 & 1 \\
\hline USA & 4,419 & 10.13 & 55,861 & .582 & 1 \\
\hline Total & 43,626 & 100.00 & 30,557 & .609 & .772 \\
\hline
\end{tabular}


In order to capture the market size we include a GDP variable. The list of variables is further augmented by a corruption perception index as the prevalence of corruption may deter foreign direct investment (e.g., Wei, 2002). Finally, of course, we utilize a dummy variable reporting the existence of Thin-Capitalization rules in the host country. While this variable is based on annual information it shows only weak variation over time. The countries considered seem to have adjusted their Thin-Capitalization rule only rarely. Table 1 provides descriptive statistics for the main variables used.

Table 2 provides some descriptive statistics on the size and geographic distribution of the foreign subsidiaries analyzed. The list of host countries includes 24 countries, 14 of these countries are EU members before 2004, 3 have joined the EU in 2004.

\section{Results}

The results for the leverage as presented in Table 3 show a significant positive impact of the tax rate: an increase in the tax rate by 10 percentage points results in an increase in the leverage by 3.4 to 4.4 percentage points depending on the specification. With a coefficient of about 0.35 the size of the coefficient in specification (2) is remarkably close to the finding of Desai, Foley, and Hines (2004) who report an impact of 0.33 in a similar specification, which also uses company-level fixed effects but replaces the local lending rate with several credit- 
market indicators. ${ }^{7}$ Specification (2) also shows a positive impact of the turnover which is in accordance to a positive impact of liquidity on the access to credit. The lending rate of the host country does not show much significance. However, as shown by Desai et al. (2004) and confirmed in Buettner et al. (2006), the local lending rate exerts offsetting effects on external and internal debt, where the latter might be more sensitive to the lending rate at the parent's location, which is absorbed by the time-specific effects. In column (3) the dummy for the existence of a Thin-Capitalization rule shows the expected negative effect suggesting that the leverage is about 5 percentage points lower in countries imposing such financing constraints. Column (4) reports results of a specification where, in addition, an interaction effect between the tax rate and the Thin-Capitalization dummy is included. The significant negative impact indicates that the tax sensitivity is reduced in countries which impose such constraints. Summing up our findings so far, the analysis of the capital structure supports the theoretical predictions. Affiliates in countries which impose Thin-Capitalization rules do have a lower leverage and do show a lower tax-sensitivity of the leverage.

A problem with the above analysis is that we have treated the tax policy in terms of tax rates and in terms of the imposition of restrictions on interest deduction as being unrelated. However, one might argue that not all countries are equally likely to impose debt restrictions. Rather, high-tax countries which should be the prime focus of tax-planning seem more likely to impose those rules. If the impact of the tax rate is non-linear, perhaps due to the convexity

\footnotetext{
${ }^{7}$ Gordon and Lee (2001) report a leverage effect of taxes using US firm-level data of about 0.36. Mintz and Weichenrieder (2005) report results for foreign affiliates of German corporations of between 0.3 and 0.57 depending on specification. Huizinga, Laeven, and Nicodème (2006) report a somewhat lower estimate of 0.27 for a sample of European corporations.
} 
of the agency cost, the interaction term with the Thin-Capitalization dummy might simply reflect the higher tax-sensitivity of high-tax countries. But, as can be seen from column (6) employing a quadratic specification, there is no evidence for corresponding non-linearities. Note that other non-linear specifications also failed to show significance.

Table 4 provides results for the size of the capital stock invested as captured by the level of Property, Plant, and Equipment (PPE). All estimations account for company-level as well as time and industry-level fixed effects. The first column employs a specification where the tax rate as well as its interaction with the depreciation allowances are considered. In accordance with theoretical predictions, a lower statutory tax rate and higher tax savings due to tax depreciation are both associated with a higher level of investment. ${ }^{8}$ With regard to the further control variables we may note, first, that the lending rate proves insignificant. One might have expected a negative effect, but, as noted above, if the local lending rate is high, relatively, external debt might become substituted by internal debt, which will not be responsive to the local lending rate. If no control for the turnover is included, the GDP shows a positive effect pointing to a positive role of the market size. Labor cost show a negative effect which is in accordance with the view that investment decisions are deterred by high labor cost provided that there is no strong capital-labor substitution in the choice of technology. While distance shows no effect in the basic estimation, the perception of

\footnotetext{
${ }^{8}$ While the statutory tax rate was adjusted in order to take account of special provisions for debt finance (see above), for the purpose of studying investment, both the basic statutory tax as well as the adjusted tax rate would matter. However, probably due to the rather small differences between the two tax rates, various alternative specification showed no significant differences.
} 
Table 3: Results: Determinants of the Leverage

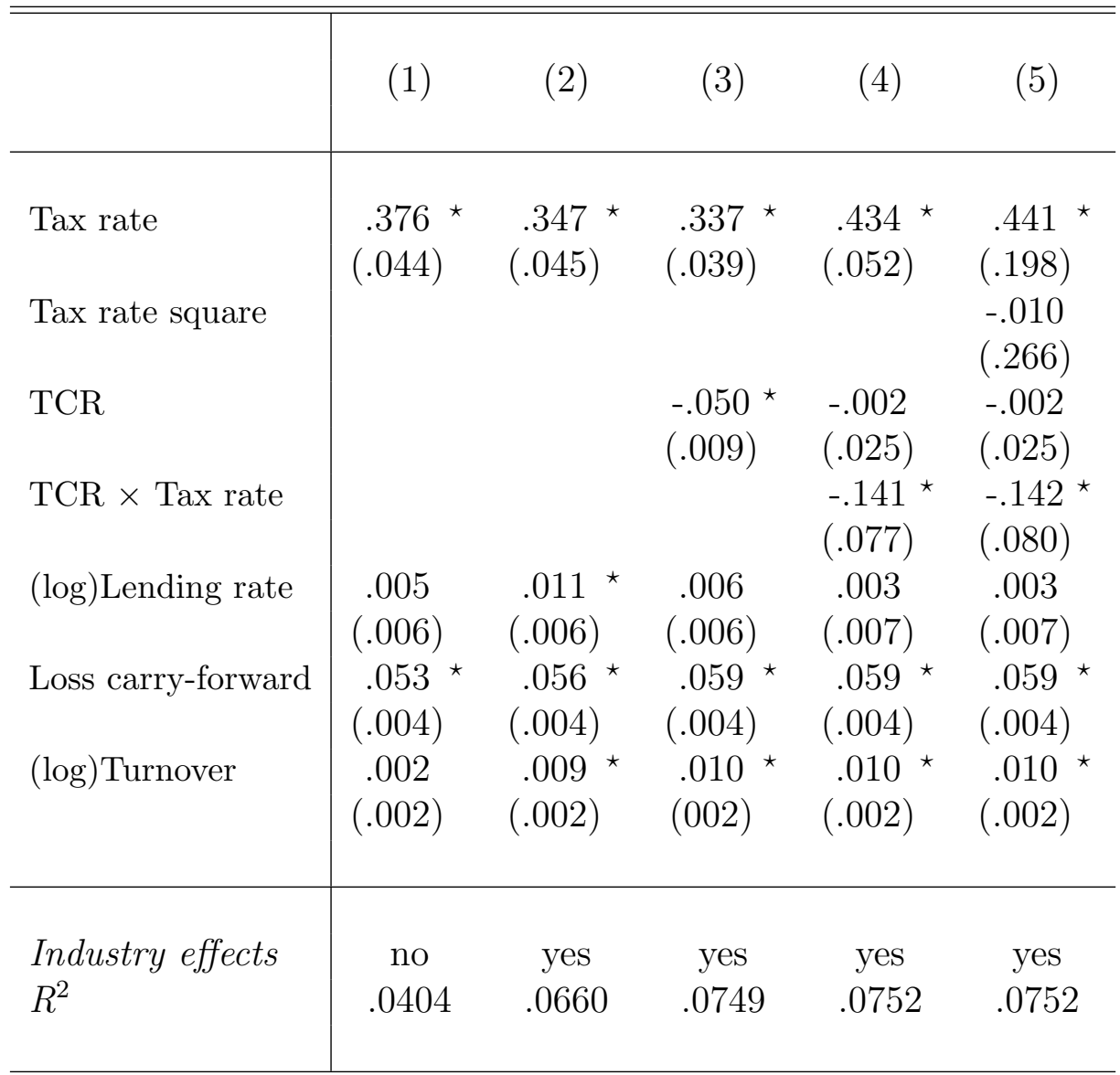

Dependent variable: Debt/asset ratio of foreign subsidiaries. Company-level and time fixed effects included. Standard errors in parentheses are robust against random firmspecific, time, and country effects using the usual Huber-White sandwich formula. An asterisk denotes significance at 5\% level. 43626 observations, 4256 firms. 
Table 4: Results: Determinants of PPE

\begin{tabular}{|c|c|c|c|c|c|c|c|}
\hline & (1) & $(2)$ & $(3)$ & $(4)$ & $(5)$ & (6) & (7) \\
\hline Tax rate & $\begin{array}{l}-1.955^{\star} \\
(.957)\end{array}$ & $\begin{array}{l}-1.90 \text { * } \\
(.912)\end{array}$ & $\begin{array}{l}-1.45^{\star} \\
(.862)\end{array}$ & $\begin{array}{l}-1.67^{\star} \\
(.709)\end{array}$ & $\begin{array}{l}-1.63^{\star} \\
(.681)\end{array}$ & $\begin{array}{l}-1.27^{\star} \\
(.652)\end{array}$ & $\begin{array}{l}-1.21 \\
(.1 .10)\end{array}$ \\
\hline Tax rate squared & & & & & & & $\begin{array}{l}-.081 \\
(1.17)\end{array}$ \\
\hline Tax rate $\times$ PVD & $\begin{array}{l}1.62 \\
(.999)\end{array}$ & $\begin{array}{l}1.644^{\star} \\
(.958)\end{array}$ & $\begin{array}{l}2.89{ }^{\star} \\
(.943)\end{array}$ & $\begin{array}{l}1.16 \\
(.754)\end{array}$ & $\begin{array}{l}1.17 \\
(.721)\end{array}$ & $\begin{array}{l}2.21 \text { * } \\
(.698)\end{array}$ & $\begin{array}{l}2.20 \star \\
(.703)\end{array}$ \\
\hline TCR & & $\begin{array}{l}.088 \text { * } \\
(.039)\end{array}$ & $\begin{array}{l}.861 \text { ^ } \\
(.131)\end{array}$ & & $\begin{array}{l}.070 \text { * } \\
(.027)\end{array}$ & $\begin{array}{l}.706 \text { 夫 } \\
(.116)\end{array}$ & $\begin{array}{l}.707 \text { ^ } \\
(.117)\end{array}$ \\
\hline Tax rate $\times$ TCR & & & $\begin{array}{l}-2.22 \text { 夫 } \\
(.338)\end{array}$ & & & $\begin{array}{l}-1.83^{\star} \\
(.309)\end{array}$ & $\begin{array}{l}-1.83 \text { * } \\
(.313)\end{array}$ \\
\hline (log) Lend. rate & $\begin{array}{l}-.001 \\
(.043)\end{array}$ & $\begin{array}{l}.012 \\
(.044)\end{array}$ & $\begin{array}{l}-.010 \\
(.040)\end{array}$ & $\begin{array}{l}.009 \\
(.032)\end{array}$ & $\begin{array}{l}.019 \\
(.033)\end{array}$ & $\begin{array}{c}.001 \\
(.030)\end{array}$ & $\begin{array}{c}.000 \\
(.030)\end{array}$ \\
\hline$(\log )$ GDP & $\begin{array}{l}.194 \text { * } \\
(.018)\end{array}$ & $\begin{array}{l}.177 \star \\
(.016)\end{array}$ & $\begin{array}{l}.166 \\
(.015)\end{array}$ & $\begin{array}{c}.012 \\
(.014)\end{array}$ & $\begin{array}{l}-.001 \\
(.013)\end{array}$ & $\begin{array}{l}-.010 \\
(.012)\end{array}$ & $\begin{array}{l}-.010 \\
(.012)\end{array}$ \\
\hline (log) Labor cost & $\begin{array}{l}-.191 \star \\
(.042)\end{array}$ & $\begin{array}{l}-.149 \star \\
(.038)\end{array}$ & $\begin{array}{l}-.153{ }^{\star} \\
(.036)\end{array}$ & $\begin{array}{l}-.263{ }^{\star} \\
(.031)\end{array}$ & $\begin{array}{l}-.229 \star \\
(.030)\end{array}$ & $\begin{array}{l}-.232 \text { * } \\
(.028)\end{array}$ & $\begin{array}{l}-.232 \star \\
(.028)\end{array}$ \\
\hline (log) Distance & $\begin{array}{l}.002 \\
(.020)\end{array}$ & $\begin{array}{l}.011 \\
(.018)\end{array}$ & $\begin{array}{l}.044{ }^{\star} \\
(.018)\end{array}$ & $\begin{array}{l}.0533^{\star} \\
(.016)\end{array}$ & $\begin{array}{l}.060{ }^{\star} \\
(.015)\end{array}$ & $\begin{array}{l}.087 \star \\
(.015)\end{array}$ & $\begin{array}{l}.087 \text { * } \\
(.015)\end{array}$ \\
\hline (log) Corruption & $\begin{array}{l}.172 \star \\
(.066)\end{array}$ & $\begin{array}{l}.125 \star \\
(.068)\end{array}$ & $\begin{array}{l}.233^{\star} \\
(.066)\end{array}$ & $\begin{array}{l}.1688^{\star} \\
(.055)\end{array}$ & $\begin{array}{l}.1311^{\star} \\
(.059)\end{array}$ & $\begin{array}{l}.219{ }^{\star} \\
(.056)\end{array}$ & $\begin{array}{l}.218 \text { * } \\
(.062)\end{array}$ \\
\hline (log) Turnover & & & & $\begin{array}{l}.748 \text { * } \\
(.013)\end{array}$ & $\begin{array}{l}.748^{\star} \\
(.013)\end{array}$ & $\begin{array}{l}.747^{\star} \\
(.013)\end{array}$ & $\begin{array}{l}.747 \\
(.013)\end{array}$ \\
\hline Loss carry-forw. & & & & $\begin{array}{l}.096 \text { * } \\
(.016)\end{array}$ & $\begin{array}{l}.094 \star \\
(.016)\end{array}$ & $\begin{array}{l}.100 \star \\
(.016)\end{array}$ & $\begin{array}{l}.100 \text { * } \\
(.016)\end{array}$ \\
\hline$R^{2}$ & .2426 & .2430 & .2446 & .4138 & .4141 & .4151 & .4151 \\
\hline
\end{tabular}

Dependent variable: logarithm of property, plant, and equipment (PPE) of foreign subsidiaries. Company level, time, and industry fixed effects included. Standard errors in parentheses are robust against random firm-specific, time, and country effects using the usual Huber-White sandwich formula. An asterisk denotes significance at 5\% level. 43626 observations, 4256 firms. 
corruption shows the expected adverse effect. ${ }^{9}$

Specification (2) includes the dummy for the existence of a Thin-Capitalization rule. Accordingly, the level of capital invested is higher in countries which impose such rules. While one can speculate whether this is attributable to the difficulties in capturing all determinants of investment decisions, we should note that this result deviates from the theoretical predictions. Specification (3) includes the interaction term with the statutory tax rate which exerts a significant negative effect. This supports the above hypothesis of a higher tax sensitivity of capital if a Thin-Capitalization rule is imposed. This specification shows a strong increase in the value of the Thin-Capitalization dummy as well, but an evaluation of this coefficient around the mean reveals that the mean difference in the level of PPE between countries imposing restrictions and those, which don't, is preserved. Columns (4) to (6) of Table 4 report results, where we include, in addition, two firm-specific controls, turnover and loss carry-forward, which have been used in the above leverage regressions. The results do not change much, except that distance now shows strong positive effects. This seems reasonable given that the specification conditions on the attractiveness of the market as captured by the turnover variable.

The wrong sign of the Thin-Capitalization dummy again points at the above mentioned problem that we have not explored the reasons behind the decision to impose debt-restrictions. Again, to make sure that the interaction with the Thin-Capitalization dummy is not just reflecting a higher tax-sensitivity of high-tax countries, we tested for nonlinear effects in the

\footnotetext{
${ }^{9}$ Note that the index is computed such that a lower perception results in a higher value.
} 
tax rate. Representative for those estimations, the table reports a specification with the squared tax rate in column (7) which does not show a significant impact. Thus, once again, the significance of the interaction effect between Thin-Capitalization rule and the tax rate cannot simply be ascribed to non-linearities in the impact of the tax rate.

We can summarize the results for the level of investment in terms of property, plant, and equipment by stating that the theoretical expectations are met only partly by the empirical evidence. While we could not find an adverse effect of the existence of Thin-Capitalization rules on the level of investment, the tax sensitivity is found to be increased. To some extent the failure to get stronger results is related to the low time-series variation in the imposition of Thin-Capitalization rules which prevent the use of more robust empirical approaches as for instance the inclusion of country-specific effects.

\section{Conclusions}

The theoretical analysis has shown that the imposition of Thin-Capitalization rules tends to reduce the leverage and the capital stock of affiliates located in countries imposing such rules. Further comparative static effects point at a lower tax sensitivity of the debt-asset ratio in countries imposing those rules. The tax sensitivity of the capital stock invested in a country should, however, be increased in the presence of Thin-Capitalization rules.

The empirical investigation of the leverage and the value of property, plant, and equipment 
of the affiliates of German multinationals in 24 countries in the period between 1996 and 2004 offers some support for the theoretical predictions. The leverage in countries with Thin-Capitalization rules is found to be reduced significantly, suggesting that these rules cannot easily be circumvented. Also the lower tax sensitivity of the leverage is confirmed in the estimations. While there is some reason to believe that Thin-Capitalization rules are mainly imposed by high-tax countries, the results indicate that the higher tax sensitivity is not simply caused by non-linear effects in the tax rate.

With regard to the level of property, plant, and equipment held by an affiliate, the analysis confirms the usual determinants found in previous empirical studies: lower tax rates, a higher present value of tax depreciation allowances, a higher level of GDP, and a lower level of corruption all exert positive effects. While the sensitivity to the statutory tax rate is found to be higher in countries where a Thin-Capitalization rule is imposed, the amount of capital invested is not lower in countries, which impose a Thin-Capitalization rule. Of course, this result may be due to some omitted variable problem. But, the low variation in the imposition of Thin-Capitalization rules over time prevents us from further exploration of this point.

The higher tax sensitivity of investment under the restriction of a Thin-Capitalization rule suggests that the adverse consequences of taxation on investment become stronger if the government imposes those restrictions. In a non-cooperative setting, therefore, tax policy faces a difficult trade-off between the real consequences of corporate taxation and the rev- 
enue loss from the tax-planning of multinationals. As not restricting tax-planning would basically mean that the tax system discriminates against locally operating firms, and, thus, also distorts the decision to operate multinationally rather than domestically (Bucovetsky and Haufler, 2005), there seem to be good reasons to impose restrictions on interest deduction. Thus, the higher tax sensitivity of investment under those constraints predicted by the theory and confirmed by the empirical analysis suggests that an optimal policy should combine a restriction on tax-planning by means of debt finance with a reduction in the overall tax burden on corporate profits. Just by imposing restrictions, policy cannot escape the fundamental question about the corporation tax raised by the process of globalization.

\section{Datasources and Definitions}

Firm-level data are taken from the micro-level dataset (MiDi) of the Bundesbank, see Lipponer (2006) for an overview. The leverage is determined by the level of balancesheet liabilities divided by total capital consisting of registered capital, capital reserves and profit reserves.

Corporate taxation data are taken from the IBFD, and from tax surveys provided by the tax advisory companies Ernst\&Young, PwC and KPMG. The statutory tax rate variable contains statutory profit tax rates modified by applicable restrictions on interest deductions.

Thin-Capitalization information is from the same source as the tax data.

Present values of depreciation are calculated for investments in machinery, assuming a discount rate of 7.1 percent. Depreciation rules are taken from the references considered in case of corporate taxation data (see above).

Lending rates refer to credits to the private sector taken from the IMF International Financial Yearbook (2005) augmented with corresponding ECB figures. 
GDP in U.S. Dollars, nominal. Source: World Economic Outlook Database.

Hourly compensation of workers: Hourly compensation costs in U.S. Dollars for production workers in manufacturing. Source: U.S. Bureau of Labor Statistics and Eurostat.

Distance is taken from "www.etn.nl/distance.htm".

Corruption Perception Index is published annually by Transparency International which ranks countries in terms of perceived levels of corruption, as determined by expert assessments and opinion surveys. The scores used range from 10 (country perceived as virtually corruption-free) to 0 (country perceived as almost totally corrupt).

\section{References}

Auerbach, A.J. (2002), Taxation and corporate financial policy, in: Auerbach A.J. and M. Feldstein (ed.), Handbook of Public Economics, Vol. 3, Amsterdam, 1251-1292.

Bucovetsky, S. and A. Haufler (2005), Tax competition when firms choose their organizational form: Should tax loopholes for multinationals be closed?, University of Munich, Discussion Paper 2005-23.

Buettner, T., M. Overesch, U. Schreiber, and G. Wamser (2006), Taxation and capital structure choice - evidence from a panel of German multinationals, paper presented at the 2006 IIPF conference in Cyprus.

Desai, M.A., (2005), The degradation of reported corporate profits, The Journal of Economic Perspectives 19, 171-192.

Desai, M.A., C.F. Foley and J.R. Hines (2004), A multinational perspective on capital structure choice and internal capital markets, The Journal of Finance 59, 2451-2487.

Gravelle, J. G. (2004), The corporate tax: where has it been and where is it going, National Tax Journal, 57, 903-923. 
Gresik, T. A. (2001), The taxing task of taxing transnationals, Journal of Economic Literature, 39, 800-838.

Gordon, R.H. and Y. Lee (2001), Do taxes affect corporate debt policy? Evidence from U.S. corporate tax return data, Journal of Public Economics, 82, 195 - 224.

Huizinga, H., L. Laeven, and G. Nicodème (2006), Capital structure and international debt shifting in Europe, ETPF Research Paper, London.

Janeba, E. and M. Smart (2003), Is targeted tax competition less harmful than its remedies?, International Tax and Public Finance 10, 259-280.

Keen, M. (2001), Preferential regimes can make tax competition less harmful, National Tax Journal 54, 757-762.

Lipponer, A. (2006), Microdatabase Direct Investment - MiDi. A brief guide. Bundesbank Working Paper, Frankfurt.

MacKie-Mason, J. (1990), Do taxes affect corporate financing decisions? The Journal of Finance 45, 1471-1493.

Mintz, J. and M. Smart (2004), Income shifting, investment, and tax competition: theory and evidence from provincial taxation in Canada, Journal of Public Economics 88, 1149 - 1168.

Mintz, J. and A. J. Weichenrieder (2005) Taxation and the financial structure of German outbound FDI, CESifo Working Paper 1612, Munich.

Myers, S. (2001), Capital Structures, Journal of Economic Perspectives 15, 81-102.

Panteghini, P. M. (2006), The capital structure of multinational companies under tax competition, CESifo Working Paper 1721, Munich.

Peralta, S., X. Wauthy and T. van Ypersele (2006), Should countries control international profit shifting? Journal of International Economics 68, 24-37.

Wei, S.-J. (2002), How taxing is corruption on international investors? The Review of Economics and Statistics 82, 1-11. 